\title{
Why Are U.S. Bond Yields So High?
}

Christopher J. Neely, Vice President and Economist

conomists watch 10-year sovereign yields closely

because those benchmark rates mostly determine the

cost of all long-term borrowing, by consumers or firms, in developed economies. Figure 1 shows the yield of the 10-year U.S. Treasury bond since January 2014, along with the 10-year yields of debt issued by similarly low-risk nations-the U.K., Canada, Germany, Japan, Switzerlandand the average of the non-U.S. yields. The international yields usually, but not always, move together. In particular, the U.S. 10-year Treasury yield has mostly moved with the other yields, but has risen relative to those yields since 2014 and has consistently exceeded those of peer bonds since 2014. This essay investigates why the 10 -year U.S. yield has exceeded those of other developed countries and why it has risen relative to those other yields since 2014 .

\section{Higher expected inflation, growth, and fiscal deficits raise U.S. long yields above foreign yields.}

The expected long-term inflation rate and the expected long-term real growth rate of the economy are the most important factors that influence long-term yields. If bond buyers expect higher inflation or higher real growth, they will expect higher interest rates in the future and thus will demand a higher yield on the bonds they buy today. Bond yields also depend on the uncertainty about these factors, so the volatility of expected inflation and growth also influence long-bond yields, but these variables are harder to measure and have smaller effects.

In addition, bond yields also depend on how easy it is to sell the bond, termed a liquidity premium, and the possibility of default. The premia for high-quality liquid bonds (such as those in Figure 1) are small, however, and don't explain large changes or differences in yields.

To examine the effect of inflation expectations on bond yields, Figure 2 illustrates "breakeven" 10-year inflation rates for the U.S., U.K., Canada, Germany, Japan, and the average of the non-U.S. series. These series are financial market forecasts of inflation that are computed by com-

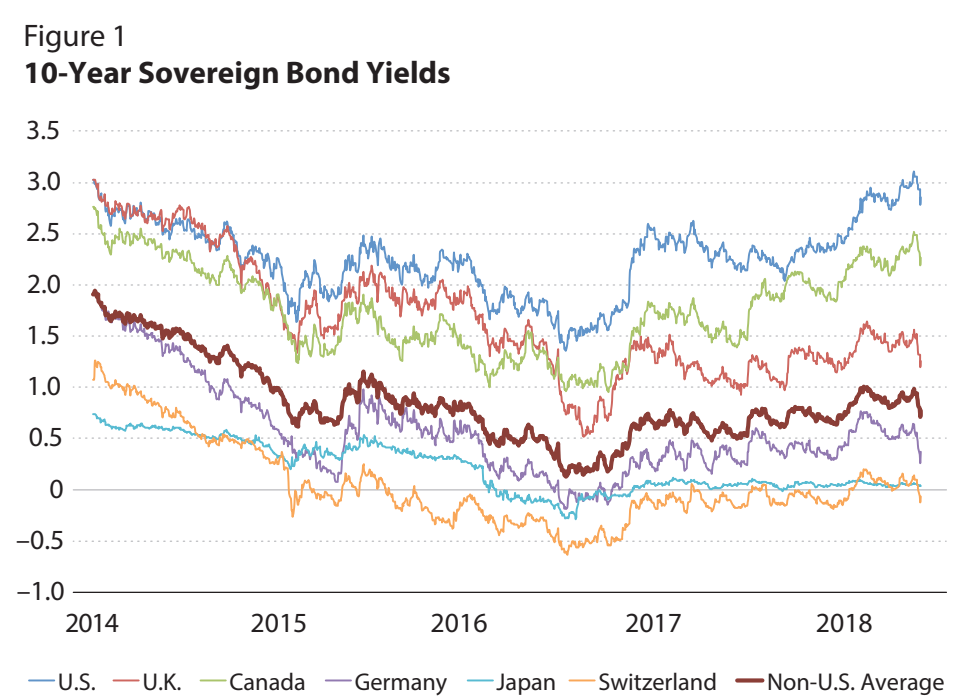

SOURCE: Bloomberg. Data span 12/31/2013 to 5/30/2018.

Figure 2

10-Year "Breakeven" Expected Inflation Rates

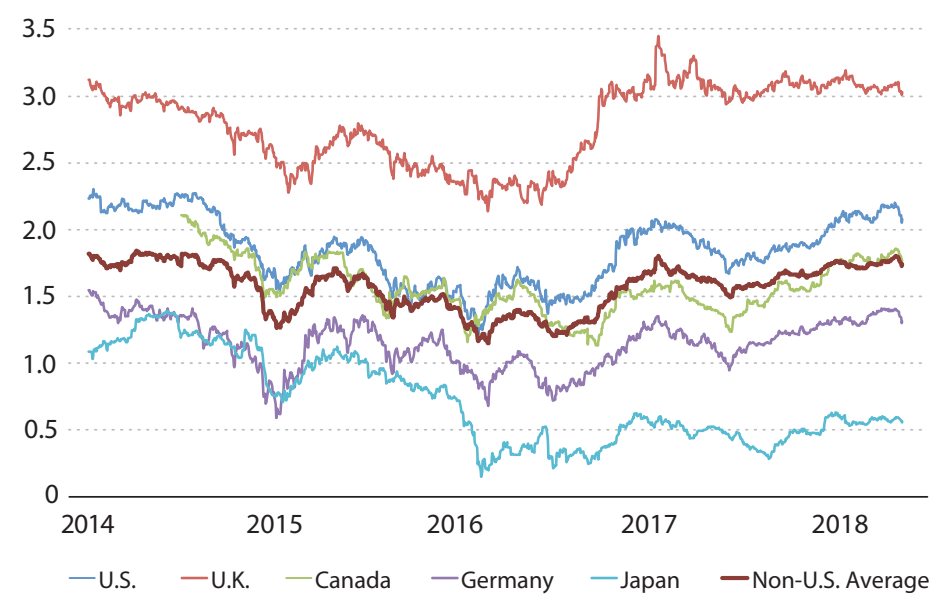

SOURCE: Bloomberg. Data span 12/31/2013 to 5/30/2018.

paring the yields of bonds whose payoffs are adjusted for inflation to the yields of bonds whose payoffs are not so adjusted. Although the inflation rates for the different countries are not completely comparable because they weight goods and services differently, their relative movements are informative as to changes in expectations about infla- 


\section{Expected International Growth and Fiscal Deficits}

\begin{tabular}{lcc} 
Country & $\begin{array}{c}\text { IMF forecast of real GDP } \\
\text { growth rates, 2018-23 }\end{array}$ & $\begin{array}{c}\text { IMF forecast of fiscal balance as } \\
\text { a percentage of GDP, 2018-23 }\end{array}$ \\
\hline Canada & 1.82 & -0.73 \\
\hline Germany & 1.65 & 1.53 \\
\hline Japan & 0.68 & -2.42 \\
\hline Switzerland & 1.87 & 0.33 \\
\hline United Kingdom & 1.57 & -1.17 \\
\hline United States & 2.02 & -5.43 \\
\hline Advanced economies & 1.85 & -2.38 \\
\hline
\end{tabular}

SOURCE: IMF.

tion. Other things equal, one would expect an increase in the breakeven inflation rate to be associated with an increase in bond yields.

Figure 2 shows that the U.S. breakeven inflation rate is about 30 basis points higher than the non-U.S. average, and this might explain the higher overall U.S. yields. But this gap in inflation expectations hasn't changed much since 2014 , so it probably isn't responsible for the increase in U.S. yields relative to other low-risk nations since that year.

One factor that might contribute to the higher yields is higher relative expected growth in the U.S. compared with the other countries in the sample. In fact, the International Monetary Fund (IMF) does forecast higher growth for the U.S. during 2018-23 than for the other countries in the sample, at 2.02 percent and 1.52 percent, respectively (see the table). ${ }^{1}$

The expected future supply of bonds also matters for current bond prices. The IMF forecasts that, from 2018-23, the U.S. will run a much higher fiscal deficit as a percentage of GDP than the other countries in the sample, at 5.43 percent and 0.50 percent, respectively. ${ }^{2}$ Supporting this inference is the fact that U.S. 10-year Treasury yields jumped by 7 basis points on December 19, 2017, the day the U.S. Congress approved the Tax Cuts and Jobs Act of 2017, which is widely expected to significantly increase future deficits.
In addition to the preceding factors, the European Central Bank, the Bank of Japan, and the Bank of England still have active asset purchase programs, while the Federal Reserve stopped buying new assets in October 2014 and has started reducing its bond inventory. These programs are likely to put some downward pressure on their long yields.

Default risk is not likely to be a cause of higher U.S. yields. Market estimates of default risk from credit default swaps, which are a type of "insurance" against bond defaults, imply that U.S. default risk has risen a bit since 2014 but is still quite low and comparable to the risks for the other countries in the sample.

Thus, it seems that a combination of higher expected inflation, growth, and fiscal deficits, perhaps with a contribution from non-U.S. asset purchase programs, are likely responsible for U.S. yields being higher than foreign yields. The growth in expected future fiscal deficits is likely to have contributed to the rise in relative yields.

\section{Notes}

1 Some analysts believe that the international importance of U.S. dollar assets means that global growth is an important determinant of U.S. yields.

2 An idea called the "fiscal theory of the price level" links inflation to fiscal deficits. 